\title{
Investasi Penangkapan Ikan Tuna Semi Modern oleh PT Serena Marine di Perairan Sulawesi Utara
}

\author{
Investment of Semi-Modern Tuna Fishing in North Sulawesi Sea \\ by PT Serena Marine
}

John E. H. J. FoEh ${ }^{*}$ dan Reyner Tekad Tuera ${ }^{2}$

\author{
1'Jurusan Manajemen, Fakultas Ekonomi Universitas Pelita Harapan \\ ${ }^{2}$ Alumnus FE Universitas Pelita Harapan \\ Lippo Karawaci, PO. Box 453 Tangerang 15811
}

\begin{abstract}
ABSTRAK
Ikan sebagai salah satu sumber daya alam memiliki potensi yang sangat tinggi sebagai sumber devisa negara dan pendapatan masyarakat. Teknik penangkapan yang tepat dari beberapa jenis ikan memberikan keuntungan optimal. Tujuan penelitian ini menganalisis kelayakan finansial dari teknik penangkapan semi modern ikan tuna oleh PT Serena Marine di perairan Sulawesi Utara. Metode analisis menggunakan asumsi-asumsi dan perhitungan kelayakan finansial dengan beberapa indikator seperti Net Present Value (NPV), Benefit Cost Ratio (BCR), Internal Rate of Return (IRR) termasuk rasio profitabilitas seperti Return on Assets (ROA), Return on Investment (ROI) dan Return on Equity (ROE), termasuk breakeven point (BEP) dan payback period (PBP). Hasil analisis menunjukan bahwa aktivitas bisnis perusahaan ini layak secara finansial atau menguntungkan. Hasil kalkulasi menunjukan bahwa nilai NPV positif, $\mathrm{BCR}=1,62$ atau $>1$ dan IRR adalah $46 \%$ atau lebih besar dari tingkat suku bunga dalam analisis. Sejalan dengan itu, semua nilai indikator profitabilitas di atas 1\% (menguntungkan), PBP akan tercapai pada bulan ke-25 atau sesudah 2 tahun dan 1 bulan beroperasi, BEP dalam volume penangkapan 225.380 ton dan bernilai Rp2.809.367.816. Hal tersebut menunjukkan aktivitas penangkapan ikan tuna oleh PT Serena Marine adalah layak secara finansial.
\end{abstract}

Kata kunci: investasi, penangkapan semi modern, ikan tuna

\section{ABSTRACT}

Fish as a natural resource has a very high potential as a source of foreign exchange and income. Arrest of the proper techniques of some fish species will provide optimal benefits. The objective of this study is to analyze the financial feasibility of tuna fishing of PT Serena Marine in area of North Sulawesi Sea. Through certain assumptions and calculations of financial feasibility with present value concept (NPV, BCR and IRR) and profitability ratios such as ROA, ROI and ROE, also break-even point, and payback period. The result showed that, this business activity will be feasible and profitable. The results show that based on those profitability indicators were above 1\%, NPV calculated is positive, BCR is 1.62 or $>1$ while IRR is $46 \%$ and greater than discounted interest rate using in this financial analysis, Payback period will be achieved on the year $25^{\text {th }}$ months or after 2 years of operations. It shows the activity of tuna fishing by PT Serena Marine, is feasible in financial aspect.

Key words: investment, semi-modern fishing, tuna fish

\footnotetext{
*) Korespondensi:

Lippo Karawaci, PO. Box 453 Tangerang 15811; e-mail: johnfoeh@gmail.com
} 


\section{PENDAHULUAN}

Kawasan Timur Indonesia memiliki laut luas dengan kekayaan laut sangat melimpah, tetapi sangat disayangkan pengusaha lokal belum dapat memanfaatkan hal ini secara optimal, padahal usaha di bidang ini memiliki peluang bisnis sangat prospektif. Potensi laut yang begitu besar membuka kesempatan kepada banyaknya nelayan asing memasuki perairan wilayah bagian Timur Indonesia untuk melakukan illegal fishing. Perairan Sulawesi di kawasan Timur Indonesia masih menyimpan potensi kekayaan alam bawah laut, termasuk keindahan bawah laut yang besar (Tribunnews.com, 2012). Potensi area ini sangatlah besar dan telah menjadi primadona dunia, tetapi belum dimanfaatkan secara optimal. Akibatnya, tidak jarang ditemukan nelayan asing yang masuk ke perairan laut Sulawesi untuk melakukan pencurian ikan. Berdasarkan data yang ada, baru $10 \%$ dari total luas potensi daerah perikanan tangkap di Indonesia Timur yang sudah dimanfaatkan, dimana sisanya masih termasuk daerah sangat potensial untuk digarap, khususnya untuk kategori ikan pelagis atau jenisjenis ikan yang radius migrasinya mencapai ratusan kilometer (Kementerian Kelautan dan Perikanan, 2012).

Dari sumber yang sama diperoleh informasi bahwa belakangan ini, nelayan lokal cenderung pesimis untuk mendapatkan hasil tangkapan maksimal, dikarenakan kawanan populasi ikan pelagis, khususnya tuna sudah berada semakin jauh dari daratan, karena nelayan asing telah memasang rumpon di laut lepas yang berjarak > 80 mil dari daratan, sehingga kawanan ikan pelagis termasuk cakalang merupakan pakan ikan tuna mengumpul di lokasi tersebut. Akibatnya, kawanan ikan tuna lebih banyak terkumpul di daerah sekitar rumpon. Selain tidak mendapatkan hasil tangkapan maksimal, mutu ikan tuna hasil nelayan lokal tidak dapat bersaing dengan nelayan asing, dikarenakan nelayan Indonesia terlalu lama berada di laut (8-10 hari) telah menyebabkan kesegaran ikan tuna cenderung menurun.

Ikan tuna termasuk dalam golongan ikan pelagis besar yang daerah penangkapannya menyebar luas hampir ke seluruh perairan Indonesia. Sebagai salah satu primadona makanan utama laut yang sangat digemari masyarakat lokal dan internasional, tuna tergolong dalam jenis ikan yang harganya terus meningkat dari waktu ke waktu. Meskipun harganya sudah tergolong mahal, permintaan terhadap ikan jenis ini masih sangat tinggi sampai dengan sekarang, karena di beberapa negara seperti Jepang, ikan tuna sudah merupakan komoditas sangat langka. Hal ini tidak berlaku untuk Indonesia yang populasi tunanya belum dimanfaatkan secara maksimal (Warta Pasar Ikan, 2012).

PT Serena Marine adalah sebuah bisnis penangkapan ikan tuna menggunakan pukat cincin dengan metode penangkapan semimodern. Daerah tangkapan Serena Marine adalah perairan laut Sulawesi Utara, dengan meletakkan rumpon di laut lepas untuk menciptakan habitat baru bagi ikan-ikan pelagis. Penangkapan dilakukan dengan metode semi modern di rumpon-rumpon tersebut. Penangkapan pukat cincin semi-modern dengan sistem rumpon dipilih, karena memiliki keunggulan dibanding metode tradisional (Perikanan-diy.info, 2007).

Dalam kaitan dengan potensi ikan tuna yang ada serta ketersediaan investor lokal yang akan menanamkan investasinya dalam bidang penangkapan ikan, diperlukan suatu studi kelayakan (feasibility study). Studi dimaksud merupakan bahan pertimbangan dalam mengambil suatu keputusan, apakah menerima atau menolak dari suatu gagasan usaha/proyek yang direncanakan. Pengertian layak dalam penilaian studi kelayakan adalah kemungkinan dari gagasan usaha/proyek yang akan dilaksanakan memberikan manfaat (benefit), baik dalam arti finansial maupun dalam arti sosial ekonomi. Aspek-aspek yang perlu dikaji dalam suatu rencana bisnis meliputi aspek teknis, aspek pasar dan pemasaran, aspek yuridis, aspek manajemen, aspek lingkungan, aspek finansial dan aspek sosial ekonomi lainnya (Umar, 2003).

Terlalu sering, jika kajian studi kelayakan dilakukan oleh pihak swasta, memberi penekanan pada aspek teknis dan finansial. Sejalan dengan Umar, Ibrahim (2009) menyatakan bahwa aspekaspek yang dikaji sekurang-kurangnya meliputi pasar dan pemasaran, teknis dan teknologis, organisasi dan manajemen, ekonomi dan keuangan (finansial), legal dan perizinan. Dalam kaitan dengan PT Serena Marine, kajian akan dilakukan hanya pada aspek finansial dengan menggunakan berbagai informasi aktual tentang aspek teknis, pasar dan pemasaran.

Atas semua kondisi seperti itu, maka sudah waktunya dijalankan sebuah usaha penangkapan ikan tuna dengan metode penangkapan semimodern yang mengutamakan jumlah tangkapan 
ideal dan kondisi kesegaran ikan hasil tangkapan yang lebih terjamin. Oleh karena itu diperlukan suatu upaya merangsang minat para pengusaha lokal di daerah untuk membangun bisnis penangkapan ikan semi-modern, khususnya di daerah perairan Sulawesi Utara. Selain itu, karena pengusaha di daerah Sulawesi Utara baru mengadopsi sistem penangkapan ikan semi modern tersebut, maka diperlukan kajian finansial awal, yang pada gilirannya para investor lebih berani dalam mengambil keputusan. Dengan demikian, penelitian ini bertujuan menganalisis tingkat kelayakan finansial dari usaha penangkapan ikan tuna semi modern oleh PT Serena Marine.

\section{METODOLOGI}

Penelitian ini merupakan suatu studi kasus untuk menentukan kelayakan bisnis dari suatu usaha penangkapan ikan di perairan Sulawesi Utara. Pendekatan studi didasarkan pada kajian pustaka, kajian data sekunder dan berbagai kajian terhadap hasil riset sebelumnya tentang kasus terkait. Atas dasar itu dilakukan analisis deskriptif kuantitatif terhadap kondisi riil (existing condition) untuk memprediksi gambaran hasil tindakan di masa datang. Sebagai bagian dari Analisis Kelayakan Investasi, maka penelitian ini dibatasi pada aspek analisis finansial, dengan asumsi didasarkan pada kondisi obyektif dan ilmiah bahwa aspek-aspek lainnya telah dinilai layak (feasible).

Studi dilaksanakan dengan mengumpulkan berbagai dokumen terkait statistik perikanan dan kelautan Indonesia maupun Sulawesi Utara, khususnya nilai dan volume produksi ikan tuna, pertumbuhan industri penangkapan dan penjualan ikan tuna, konsumsi ikan per kapita, jenis dan jumlah kapal penangkap ikan dan sebagainya. Estimasi produksi, penjualan dan harga akan menjadi dasar dalam melakukan analisis atau kajian finansial dari usaha penangkapan ikan tuna ini.

Analisis finansial bertujuan menilai apakah suatu kegiatan tertentu yang dilaksanakan adalah layak, atau dapat memberikan keuntungan finansial bagi suatu perusahaan atau perorangan yang bertujuan untuk memaksimumkan keuntungannya. Suatu proyek dilihat dari sudut yang bersifat individual, artinya tidak perlu diperhatikan apakah efek atau dampak dalam perekonomian dalam lingkup lebih luas. Hal terpenting dalam analisis finansial, adalah hasil total atau produktivitas atau keuntungan yang didapat dari semua sumber yang dipakai dalam proyek untuk masyarakat atau perekonomian secara keseluruhan. Untuk mengambil keputusan berdasarkan penilaian kelayakan suatu kegiatan investasi, adalah sangat penting untuk memperhitungkan semua biaya dan manfaat yang relevan dan/atau benar terjadi sebagai akibat pelaksanaan kegiatan tersebut (Kadariah, 1999).

Menurut Gray et al, (2002), kelayakan finansial suatu kegiatan ditunjukkan oleh nilai NPV (net present value), B/C atau BCR (benefit cost ratio) atau IRR (internal rate of return). Nilai NPV, BCR dan IRR sesungguhnya saling berhubungan satu sama lainnya. Suatu kegiatan dikatakan layak secara finansial (menguntungkan perusahaan), bila nilai NPV positif. Jika NPV positif, maka nilai BCR $>1$ dan nilai IRR nya lebih besar dari tingkat suku bunga diskonto (discount rate) yang digunakan dalam perhitungan NPV dimaksud. Salah satu dari tiga nilai dimaksud dapat digunakan untuk mengambil keputusan apakah suatu kegiatan akan menguntungkan (layak) atau tidak secara finansial.

Hasil perhitungan kriteria investasi merupakan indikator dari modal yang diinvestasikan, yaitu perbandingan antara total benefit yang diterima dengan total cost yang dikeluarkan dalam konteks nilai sekarang (present value) selama umur ekonomis proyek. Apabila hasil perhitungan telah menunjukkan layak (feasible), pelaksanaannya akan jarang mengalami kegagalan. Kegagalan hanya terjadi karena faktor-faktor yang tidak dapat dikendalikan (uncontrollable) seperti banjir, gempa bumi, perubahan peraturan pemerintah, di samping data yang digunakan tidak relevan (Ibrahim, 2009). Selanjutnya menurut Rangkuti (2008), kriteria pengambilan keputusan investasi dapat dilakukan melalui perhitunganperhitungan indikator pengambilan keputusan seperti; profitability ratio (Return on Assets atau ROA, Return on Investment atau ROI dan Return on Equity atau ROE), present value methods (NPV, BCR dan IRR), serta payback period (PBP).

Pertimbangan lain yang perlu dilakukan dalam rangka analisis investasi adalah melakukan suatu analisis industri, yaitu kumpulan perusahaan yang memproduksi produk atau jasa serupa. Analisis industri sangat penting disajikan pada awal sebuah rencana bisnis, karena akan memengaruhi secara logis target market dan strategi pemasaran perusahaan (Barringer, 2009). 
Dalam melakukan analisis industri, metode yang digunakan adalah Porter Five Forces Model, yaitu: (a) Persaingan dalam industri, (b) Kekuatan tawar pemasok, (c) Kekuatan tawar pembeli, (d) Kekuatan tawar menawar pelaku bisnis baru, (e) Kekuatan tawar produk pengganti. Porter dalam Hooley et al, (2008) menyarankan bahwa Five Forces Model pada tingkat bisnis unit strategi dan analisis sistematis dapat membantu manajer untuk mengidentifikasi kunci daya saing industrinya.

Alat-alat analisis yang digunakan dalam kajian finansial penangkapan ikan tuna oleh PT Serena Marine adalah:

1. Profitability Ratio:

- $\quad R O A=($ Net Income $) /($ Total Assets $)$

- $\quad R O I=($ Laba Usaha $) /($ Total Assets $)$

- $R O E=($ Profit after Tax $) /($ Net Worth $)$

2. Net Present Worth:

- $\quad$ Net Present Value $(N P V)=\sum_{t=0}^{n} \frac{(B t-C t)}{(1+i)^{t}}$

- Benefit Cost Ratio $=\sum_{t=0}^{n} \frac{B t}{(1+i)^{t}} / \frac{C t}{(1+i)^{t}}$

$I R R=\mathrm{i} 1+\frac{N P V}{N P V 1-N P V 2}(i 2-i 1)$

3. $P B P=\frac{\text { Initial }}{\text { investment }}=\frac{C 0}{C}$

4. $B E P=\mathrm{v} \cdot \mathrm{p}-\mathrm{cf}-\mathrm{cv}=0$; Atau total revenue - total cost $=0$

$\mathrm{V}_{\mathrm{BEP}}=\frac{c f}{p-c v}$, dimana; $\mathrm{v}=$ volume, $\mathrm{cf}=$ fixed cost, $\mathrm{cV}=$ variable cost, $\mathrm{p}=$ price/unit

\section{HASIL DAN PEMBAHASAN}

Secara umum dapat dikatakan bahwa sekurang-kurangnya terdapat empat pertimbangan utama dalam rangka investasi suatu proyek atau suatu rencana bisnis. Hal-hal tersebut menyangkut apakah secara ekologis/lingkungan hidup aman atau tidak untuk dilaksanakan? Jika aman, maka pertanyaan selanjutnya, apakah secara teknis bisa dikerjakan? Jika ya, maka dilanjutkan dengan pertanyaan, apakah secara ekonomis dan finansial menguntungkan? Jika ya, maka masih ada suatu pertanyaan akhir yang penting yaitu, apakah secara sosial budaya, proyek/kegiatan bisnis tersebut dapat diterima oleh masyarakat sekitar? Proyek investasi dimaksud barulah dapat dilaksanakan, jika semua jawabannya adalah ya atau bisa (FoEh, 2003).
Menurut Sutojo (2004), membangun proyek baru atau memperluas perusahaan yang telah berjalan bersifat lebih substansial dengan ciri-ciri khusus berikut:

1. Investasi tersebut menyerap dana dalam jumlah yang besar dan jangka waktu ikatan dana dapat mencapai waktu 20 tahun atau lebih. Konsekuensinya, jika terjadi kesalahan dalam analisis kelayakan rencana investasi, maka perusahaan akan menderita kerugian.

2. Manfaat yang diperoleh perusahaan (misalnya keuntungan), baru dapat diperoleh setelah beberapa bulan atau tahun setelah investasi dilaksanakan. Oleh karena itu, untuk menghitung nilai nyata manfaat tersebut dipergunakan metode khusus, misalnya discounted cash flow.

3. Tingkat risiko yang tinggi (high risks) dan faktor ketidakpastian (uncertainty) tidak hanya disebabkan oleh besarnya dana yang terikat, melainkan juga karena lamanya jangka waktu ikatannya.

4. Keputusan investasi proyek yang keliru, tidak dapat direvisi begitu saja, seperti halnya keputusan memberikan kredit penjualan kepada pelanggan baru secara tidak tepat, tanpa harus menderita kerugian cukup besar.

Selanjutnya Sutoyo (2004) mengatakan bahwa, investasi proyek dapat dilakukan oleh pemerintah ataupun investor swasta, baik perseorangan maupun perusahaan. Manfaat yang ingin dicapai para investor bermacam-macam, yaitu:

1. Manfaat finansial, seperti memperoleh keuntungan atau likuiditas keuangan.

2. Manfaat makro ekonomi, misalnya meningkatkan lapangan kerja baru, meningkatkan perdagangan termasuk ekspor, penghematan pengeluaran devisa, dll.

3. Manfaat politis, sosial, budaya dan sebagainya.

Investor swasta cenderung mengutamakan pencapaian manfaat finansial, terutama keuntungan besar, sedangkan investor badan usaha milik negara (BUMN) lebih mengetengahkan manfaat makro ekonomi dan aspek sosial politik. Namun demikian, proyek dimaksud juga tidak boleh menderita kerugian, minimum sampai dengan jangka menengah.

Pembahasan awal dimulai dengan gambaran umum industri penangkapan ikan tuna dan cakalang (skipjack) di perairan Sulawesi Utara. Nilai produksi serta volume produksi ikan tuna dan cakalang di perairan Sulawesi Utara dapat dilihat pada Tabel 1. 
Anomali cuaca telah membuat jenis ikan semakin sulit ditangkap, mengingat sebagian besar penangkap ikan di daerah Sulawesi Utara merupakan nelayan dengan peralatan kapal terbatas. Cuaca yang kurang bersahabat dan peralatan seadanya menjadi alasan utama nelayan-nelayan tersebut tidak dapat memaksimalkan hasil tangkapan. Namun demikian, industri ini tetap menunjukkan kenaikkan nyata dan memiliki prospek di pasar dalam dan luar negeri. Sehubungan dengan pertumbuhan Industri penangkapan ikan tuna, maka dalam Tabel 2, disajikan data pertumbuhan industri penangkapan ikan di perairan Sulawesi Utara.

Pertumbuhan nilai produksi yang negatif, terutama disebabkan masalah kelangka-an bahan bakar minyak (BBM) pada waktu itu, termasuk dampak kenaikkan harga BBM untuk operasional dan juga melemahnya daya beli masyarakat akibat kenaikan tersebut. Naiknya biaya BBM memicu meningkatnya biaya operasional, terutama untuk kapal bermotor yang sangat bergantung kepada bahan bakar solar. Selanjutnya dapat dikatakan bahwa sekalipun dengan jumlah penduduk Sulawesi Utara yang mencapai 2,2 juta jiwa, dimana jenis ikan ini juga merupakan sumber gizi masyarakat lokal maka BPS Sulut memproyeksi-kan bahwa konsumsi ikan tuna di provinsi akan mencapai 400-500 ton per tahunnya (BPS Sulut, 2012).

Industri penangkapan ikan tuna diproyeksikan akan meningkat setiap tahunnya, seiring dengan kebijakan pemerintah untuk menggalakkan penangkapan ikan tuna dengan menyediakan kapal-kapal bantuan dan sarana fasilitas laboratorium. Sampai saat ini, penangkapan ikan di Sulawesi Utara didominasi oleh kapal jukung, kapal motor tempel, dan perahu tanpa motor.

Untuk membahas kelayakan usaha dari PT Serena Marine atas dasar perhitunganperhitungan kuantitatif yang telah dilakukan, maka disajikan beberapa asumsi berikut:

1. Dalam operasinya, PT Serena Marine dibantu dua buah armada darat berupa truk untuk mengangkut hasil tangkapan segar ke pembeli di tempat pendaratan ikan (TPI) Bitung dan Manado.

2. Tren pasar menunjukkan bahwa ikan tuna merupakan primadona ekspor nomor satu dan pasar internasional masih membutuh-kan tuna dari Indonesia.

Tabel 1. Nilai produksi dan volume produksi Tuna di Sulawesi Utara, tahun 2007-2011

\begin{tabular}{|c|c|c|c|c|c|c|}
\hline $\begin{array}{l}\text { Jenis } \\
\text { Ikan }\end{array}$ & Uraian & 2007 & 2008 & 2009 & 2010 & 2011 \\
\hline \multirow{2}{*}{ Tuna } & Nilai Produksi (xRp. 1.000,-) & 306.683 .690 & 321.717 .495 & 459.588 .365 & 360.032 .830 & 371.092 .950 \\
\hline & Volume Produksi (ton) & 45.315 & 48.709 & 46.962 & 54.941 & 56.658 \\
\hline \multirow{3}{*}{$\begin{array}{c}\text { Skipjack } \\
\text { Tuna }\end{array}$} & Nilai Produksi (xRp. 1.000,-) & 542.451 .175 & 521.467 .285 & 813.272 .665 & 475.863 .015 & 487.626 .125 \\
\hline & Volume Produksi (ton) & 89.154 & 83.033 & 89.819 & 83.130 & 85.493 \\
\hline & Jumlah Pukat Cincin & 786 & 863 & 898 & 1070 & 933 \\
\hline \multicolumn{2}{|r|}{ Konsumsi Ikan per Kapita } & 23,95 & 25,03 & 26 & 28 & 29,08 \\
\hline
\end{tabular}

Sumber: Kementerian Kelautan dan Perikanan, 2012.

Tabel 2. Pertumbuhan industri penangkapan ikan Tuna di Sulawesi Utara (\%)

\begin{tabular}{|c|c|c|c|c|c|c|c|}
\hline \multirow{2}{*}{$\begin{array}{l}\text { Jenis } \\
\text { Ikan }\end{array}$} & \multirow{2}{*}{ Uraian } & \multirow{2}{*}{2008} & \multirow{2}{*}{2009} & \multirow{2}{*}{2010} & \multirow{2}{*}{2011} & \multicolumn{2}{|c|}{ Kenaikan Rataan } \\
\hline & & & & & & 2005-2009 & 2008-2009 \\
\hline \multirow{2}{*}{ Tuna } & $\begin{array}{l}\text { Pertumbuhan Nilai } \\
\text { Produksi }\end{array}$ & 4,67 & 30,00 & $-27,65$ & 2,98 & 7,29 & 3,87 \\
\hline & \% Volume Produksi & 6,97 & $-3,72$ & 14,52 & 3,03 & 6,00 & 3,13 \\
\hline \multirow{2}{*}{$\begin{array}{l}\text { Skipjack } \\
\text { Tuna }\end{array}$} & $\begin{array}{l}\text { \% Pertumbuhan Nilai } \\
\text { Produksi }\end{array}$ & $-4,02$ & 35,88 & $-70,9$ & 2,41 & 3,27 & 2,47 \\
\hline & \% Volume Produksi & $-7,37$ & 7,56 & $-8,05$ & 2,8 & $-0,82$ & 2,84 \\
\hline \multicolumn{2}{|c|}{ \% Konsumsi Ikan per Kapita } & 4,31 & 3,73 & 7,14 & 3,75 & 4,73 & 5,45 \\
\hline
\end{tabular}

Sumber: Kementerian Kelautan dan Perikanan, 2012. 
3. Fasilitas yang dimiliki oleh Serena Marine cukup lengkap, meliputi satu unit radio, satu unit global positioning system (GPS), satu unit fish finder, satu unit radar dan pukat cincin dengan panjang $600 \mathrm{~m}$ dan kedalaman $200 \mathrm{~m}$.

4. Sumber daya manusia (SDM) berpengalaman dalam operasi PT Serena Marine.

5. Tingginya permintaan tuna berarti peluang ekspor makin besar.

6. Atas dasar kapasitas kapal dan peralatan yang dimiliki dan dibanding pesaing, maka diestimasi hasil penangkapan di tahun pertama mencapai $154.000 \mathrm{~kg}$ ikan tuna dan skipjack tuna (cakalang). Hasil tangkapan tahun-tahun berikut akan terus meningkat seperti pada Lampiran 1.

7. Pada tahun pertama, ditetapkan harga promosi per kg adalah Rp12.465 (lebih murah 10\% dibanding tahun kedua). Tahun kedua sampai tahun keempat harga jual mulai ditetapkan Rp13.850. Pada tahun kelima ada kenaikan harga jual 5\% menjadi Rp14.543.

8. Cost of goods sold (COGS) adalah $13 \%$ pada tahun pertama dan kedua, $14 \%$ pada tahun ketiga, 15\% pada tahun keempat dan 16,5\% pada tahun kelima dan keenam. Komponen yang termasuk dalam COGS adalah es batu dan biaya distribusi.

9. Berdasarkan data dari panduan teknis penangkapan ikan, biasanya untuk 1 ton ikan diperlukan 1 ton es yang dapat berta-han selama 1 minggu. Berarti pemakaian es dan ikan adalah 1:1. atau $1 \mathrm{~kg}$ ikan $=0,75 \mathrm{~kg}$ es, mengingat waktu melaut Serena Marine hanya 3 hari 2 malam.

10. Komponen yang masuk dalam COGS adalah biaya pengantaran hasil tangkapan ke pembeli, yaitu biaya distribusi untuk $1 \mathrm{~kg}$ ikan adalah Rp1.000.

11. Total gaji per bulan adalah tetap Rp59.500.000, dengan kenaikan hanya pada tahun kelima 5\% ditambah tunjangan hari raya (THR) yang dibayarkan setiap bulan Desember.

12. Bekal konsumsi adalah meliputi beras, sayur, daging, makanan ringan, kopi selama 3 hari 2 malam untuk 18 (delapan belas) orang adalah Rp1.500.000 per trip

13. Solar untuk keperluan melaut 1.500 liter sudah termasuk bahan bakar cadangan, yang didapatkan dengan rumus berikut:
a. Konsumsi $=0,75 \times$ Daya Maksimum
Mesin (HP) $x$ densitas BBM $\times 0.001$
b. Konsumsi $=0,75 \times 630 \times 180 \times 0,001$

c. Konsumsi per jam $=85,05$ liter

Keterangan:

Mesin digunakan jenis turbo diesel 630 HP

Sumber: Prado and Dremiere, 2005.

14. Dengan penggunaan mesin $630 \mathrm{HP}$, kapal diperkirakan akan melaju dengan kecepatan 18 knot. Berdasarkan data kecepatan dan jarak yang ditempuh, setiap kali melaut diperlukan waktu sekitar lima jam sampai ke lokasi penangkapan. Dengan konsumsi bahan bakar 85.05 liter/jam kondisi kapal jalan, ditambah dengan pemakaian BBM untuk generator dengan BBM cadangan, maka diestimasi total pengeluaran biaya BBM per trip Rp6.750.000.

15. Pada tahun keempat terjadi penambahan aset berupa satu unit kapal, satu set jaring dan rumpon, satu set mesin-mesin, satu set peralatan kantor dan kapal, serta satu set komputer.

16. Pada tahun keempat, khusus gaji pemilik, staf darat, supir dan administrasi naik sebesar $50 \%$, seiring dengan adanya penambahan armada.

17. Pembelian jaring dan rumpon sebesar Rp490.000.000 dan mengalami penyusutan (depresiasi) selama 4 tahun.

18. Pembelian peralatan dan perlengkapan kantor, kapal juga kas ikan Rp145.000.000 dan mengalami penyusutan (depresiasi) selama 4 tahun.

19. Pembelian komputer Rp5.000.000 dan mengalami penyusutan selama 4 tahun.

20. Pembelian mobil Rp400.000.000 dan mengalami penyusutan selama 8 tahun.

21. Pembelian body kapal Rp850.000.000 dan mengalami penyusutan selama 8 tahun.

22. Pembelian mesin-mesin Rp395.000.000 dan mengalami penyusutan selama 8 tahun.

23. Pembelian bangunan Rp55.000.000 dan mengalami penyusutan selama 20 tahun.

24. Pajak yang harus dibayar atas pendapatan perusahaan sebesar $25 \%$.

25. Setiap tahun ada pengambilan prive $30 \%$ dari total keuntungan

\section{Kriteria Pengambilan Keputusan Investasi PT Serena Marine}

Hasil kalkulasi sebagaimana tercantum dalam Lampiran 1-4 memperlihatkan secara umum dapat diputuskan bahwa industri penangkapan ikan oleh PT Serena Marine di perairan Sulawesi Utara adalah layak dari segi 
finansial. Untuk menjalankan bisnis ini, diperlukan modal awal Rp2.500.000.000 dengan rincian seperti pada Tabel 3.

Laporan laba rugi merefleksikan seluruh pendapatan dan pengeluaran sebuah perusaha-an dalam waktu tertentu dan menunjukkan apakah perusahaan mendapatkan untung atau rugi (Barringer, 2009,). Pada Tabel 4 disajikan proyeksi laba rugi perusahaan selama 6 (enam) tahun mulai dari tahun produksi 2015.

Laporan proyeksi arus kas mengindikasikan apakah perusahaan mampu menjaga keseimbangan kas cukup untuk bangun dan berjalan dengan sukses (Barringer, 2009). Tabel 5 menyajikan proyeksi Cash Flow PT Serena Marine.

\section{Analisis Rasio Keuangan}

Cara yang paling praktis untuk menginterpretasikan atau memahami sejarah atau pernyataan laporan keuangan perusahaan adalah melalui analisis rasio (Barringer, 2009). Rasio keuangan PT Serena Marine disajikan dalam Tabel 6. Data pada Tabel 6 menunjukkan bahwa PT Serena Marine mengalami peningkatan dari segi profitabilitas, terlihat dari peningkatan pada ROI, ROA dan ROE setiap tahun.

\section{Analisis PBP}

Analisis ini dilakukan untuk mengetahui kapan modal yang diinvestasikan kembali. Berdasarkan analisis tersebut, bisnis PT Serena Marine mengalami PBP saat perusahaan beroperasi selama 2,1 tahun atau 25 bulan.

\section{Perhitungan IRR, NPV dan BEP}

Berdasarkan hasil perhitungan yang disajikan dalam Lampiran 2, angka yang didapatkan dengan analisis bisnis selama 6 tahun, diperoleh nilai IRR $46 \%$, yang dalam hal ini jelas lebih menguntungkan dibandingkan menyimpan uang dalam bentuk deposito di bank. Selanjutnya dengan hasil perhitungan yang sama dalam Lampiran 2, diperoleh nilai NPV positif (Rp5.038.661.346) dan selanjutnya menunjukkan bahwa BEP dalam volume penangkapan 225.380 ton dan dalam nilai Rp2.809.367.816.
Tabel 3. Perincian penggunaan modal awal

\begin{tabular}{|c|c|}
\hline Keterangan & Jumlah (Rp) \\
\hline \multicolumn{2}{|l|}{ Sarana dan Prasarana: } \\
\hline Pembelian tanah & 4.000 .000 \\
\hline Pembuatan kantor dan gudang & 55.000 .000 \\
\hline Pembelian bodi kapal & 850.000 .000 \\
\hline Pengadaan jaring cincin & 350.000 .000 \\
\hline Pembuatan rumpon & 140.000 .000 \\
\hline Pembelian kendaraan (2 unit truk) & 400.000 .000 \\
\hline Mesin induk kapal & 350.000 .000 \\
\hline Generator & 40.000 .000 \\
\hline Mesin pompa air & 5.000 .000 \\
\hline $\begin{array}{l}\text { Peralatan dan perlengkapan kapal } \\
\text { Pembelian kas ikan (100 buah @ Rp. } \\
100.000,-)\end{array}$ & $\begin{array}{r}125.000 .000 \\
10.000 .000\end{array}$ \\
\hline Peralatan Kantor dan Gudang & 10.000 .000 \\
\hline Komputer & 5.000 .000 \\
\hline Instalasi telepon, listrik, dan air & 5.000 .000 \\
\hline Biaya Pembuatan Website & 5.000 .000 \\
\hline Pengurusan perizinan & 20.000 .000 \\
\hline Total & 2.374.000.000 \\
\hline \multicolumn{2}{|l|}{ GAJI } \\
\hline Pemilik & 10.000 .000 \\
\hline Kapten & 5.000 .000 \\
\hline Teknisi (2 orang @ Rp. 3.500.000,-) & 7.000 .000 \\
\hline Staf darat & 3.500 .000 \\
\hline Supir (2 orang @ Rp. 2.500.000,-) & 5.000 .000 \\
\hline Administrasi & 2.000 .000 \\
\hline ABK (15 orang @ Rp. 1.800.000,-) & 27.000 .000 \\
\hline $\begin{array}{r}\text { Total } \\
\end{array}$ & 59.500 .000 \\
\hline \multicolumn{2}{|l|}{ BEKAL MELAUT } \\
\hline Solar (2.500 liter) & 11.250 .000 \\
\hline Es batu 25kg (120 buah @Rp. 20.000,-) & 2.400 .000 \\
\hline Bekal konsumsi & 1.500 .000 \\
\hline Total & 15.150 .000 \\
\hline Total Dana Dikeluarkan & 2.448.650.000 \\
\hline Sisa Kas & 51.350 .000 \\
\hline Total Modal & 2.500 .000 .000 \\
\hline
\end{tabular}


Tabel 4. Proyeksi Laba Rugi (dalam Rp).

\begin{tabular}{|c|c|c|c|c|c|c|}
\hline PROFIT AND LOSS & 2015 & 2016 & 2017 & 2018 & 2019 & 2020 \\
\hline \multicolumn{7}{|l|}{ Sales } \\
\hline Penjualan/bln & 154.000 & 250.000 & 308.200 & 458.500 & 536.445 & 627.641 \\
\hline Harga/kg & 12.465 & 13.850 & 13.850 & 13.850 & 16.205 & 16.205 \\
\hline Tot. Sales & 1.919.610.000 & 3.462 .500 .000 & 4.268 .570 .000 & 6.350 .225 .000 & 8.692 .823 .003 & 10.170.602.913 \\
\hline COGS & 239.826 .600 & 341.333.333 & 586.353 .600 & 710.505 .000 & 869.282 .300 & 869.282 .300 \\
\hline $\begin{array}{l}\text { Gross profit } \\
\text { Gross margin (\%) } \\
\text { Expenses }\end{array}$ & $\begin{array}{r}1.679 .783 .400 \\
87,5\end{array}$ & $\begin{array}{r}3.121 .166 .667 \\
\mathbf{9 0 , 1 0}\end{array}$ & $\begin{array}{r}3.682 .216 .400 \\
86,30\end{array}$ & $\begin{array}{r}5.639 .720 .000 \\
\mathbf{8 8 , 8 0}\end{array}$ & $\begin{array}{r}7.823 .540 .702 \\
\mathbf{9 0 , 0 0}\end{array}$ & $\begin{array}{r}9.301 .320 .613 \\
\mathbf{9 1 , 5 0}\end{array}$ \\
\hline Gaji Karyawan per bulan & 773.500 .000 & 773.500 .000 & 773.500 .000 & 1.413 .750 .000 & 1.654.087.500 & 1.654.087.500 \\
\hline Listrik per bulan & 6.000 .000 & 6.000 .000 & 6.000 .000 & 6.000 .000 & 7.020 .000 & 7.020 .000 \\
\hline Air per bulan & 6.000 .000 & 6.000 .000 & 6.000 .000 & 6.000 .000 & 7.020 .000 & 7.020 .000 \\
\hline Telepon per bulan & 6.000 .000 & 6.000 .000 & 6.000 .000 & 6.000 .000 & 7.020 .000 & 7.020 .000 \\
\hline Bekal konsumsi & 72.000 .000 & 120.000 .000 & 138.000 .000 & 264.000 .000 & 308.880 .000 & 308.880 .000 \\
\hline $\begin{array}{l}\text { Solar melaut } \\
\text { (kapal+genset) }\end{array}$ & 324.000 .000 & 648.000 .000 & 540.000 .000 & 1.695 .750 .000 & 1.984.027.500 & 1.984.027.500 \\
\hline Biaya Pemeliharaan & 24.000 .000 & 24.000 .000 & 24.000 .000 & 24.000 .000 & 24.000 .000 & 24.000 .000 \\
\hline Total Expenses & 1.211 .500 .000 & 1.583 .500 .000 & 1.493 .500 .000 & 3.415 .500 .000 & 3.992 .055 .000 & 3.992 .055 .000 \\
\hline EBITDA & 468.283 .400 & 1.537.666.667 & 2.188 .716 .400 & 2.224 .220 .000 & 3.831 .485 .702 & 5.309 .265 .613 \\
\hline EBITDA margin (\%) & 24,40 & 44,40 & 51,30 & 35,00 & 44,10 & 52.20 \\
\hline Depresiasi & 368.375 .000 & 368.375 .000 & 368.375 .000 & 368.375 .000 & 368.375 .000 & 368.375 .000 \\
\hline Interest Expense & 255.000 .000 & 191.250 .000 & 127.500 .000 & - & - & - \\
\hline Profit before tax & -155.091 .600 & 978.041 .667 & 1.692 .841 .400 & 1.855 .845 .000 & 3.463 .110 .702 & 4.940 .890 .613 \\
\hline $\operatorname{Tax} 25 \%$ & -38.772 .900 & 244.510 .417 & 423.210 .350 & 463.961 .250 & 865.777 .676 & 1.235.222.653 \\
\hline Net Income & -116.318 .700 & 733.531 .250 & 1.269 .631 .050 & 1.391 .883 .750 & 2.597.333.027 & 3.705 .667 .960 \\
\hline
\end{tabular}

Sumber: Hasil analisis.

Tabel 5. Proyeksi Arus Kas PT Serena Marine (Rp)

\begin{tabular}{|c|c|c|c|c|c|c|}
\hline CASH FLOW & $2015 \backslash$ & 2016 & 2017 & 2018 & 2019 & 2020 \\
\hline Operating Activities & -116.318 .700 & & & & & \\
\hline Net Profit & 368.375 .000 & 733.531 .250 & 1.269 .631 .050 & 1.391 .883 .750 & 2.597.333.027 & 3.705 .667 .960 \\
\hline Add: Depresiasi & 100.150 .000 & 368.375 .000 & 368.375 .000 & 684.000 .000 & 368.375 .000 & 368.375 .000 \\
\hline Perubahan aset lancar & 352.206 .300 & & & & & \\
\hline Total Operating Activities & & 1.101 .906 .250 & 1.638 .006 .050 & 2.075.883.750 & 2.965.708.027 & 4.074.042.960 \\
\hline Investing Activities & - & & & & & \\
\hline Capital Expenditure & & - & - & & & \\
\hline Kapal & & & & -850.000 .000 & & \\
\hline Jaring & & & & -490.000 .000 & & \\
\hline Mesin & & & & -395.000 .000 & & \\
\hline Peralatan & & & & -145.000 .000 & & \\
\hline Komputer & & & & -5.000 .000 & & \\
\hline Financing Activities & - & & & & & \\
\hline Payment Loan & & -500.000 .000 & -500.000 .000 & -500.000 .000 & -500.000 .000 & - \\
\hline Capital Investment & 34.895 .610 & & & & & \\
\hline Prive & 34.895 .610 & -220.059 .375 & -380.889 .315 & -417.565 .125 & -779.199 .908 & -1.111 .700 .388 \\
\hline Total Financing Activities & 387.101 .910 & -720.059 .375 & -880.889 .315 & -917.565 .125 & -1.279 .199 .908 & -1.111 .700 .388 \\
\hline Increase/Decrease in Cash & 55.850 .000 & 381.846 .875 & 757.116 .735 & -726.681 .375 & 1.686.508.119 & 2.962 .342 .572 \\
\hline Beginning Cash & 442.951 .910 & 442.951 .910 & 824.798 .785 & 1.581.915.520 & 689.531 .020 & 2.376 .039 .139 \\
\hline Ending Cash & & 824.798 .785 & 1.581.915.520 & 855.234.145 & 2.376.039.139 & 5.338.381.710 \\
\hline
\end{tabular}


Tabel 6. Rasio keuangan PT Serena Marine (dalam \%)

\begin{tabular}{|c|c|c|c|c|c|c|}
\hline Tahun & 2015 & 2016 & 2017 & 2018 & 2019 & 2020 \\
\hline NPM & $-6,10$ & 21,20 & 29,70 & 21,90 & 29,90 & 36,40 \\
\hline ROE & $-27,80$ & 78,70 & 69,70 & 49,80 & 58,40 & 52,60 \\
\hline ROA & $-4,80$ & 30,20 & 45,00 & 42,20 & 58,40 & 52,60 \\
\hline ROI & 4,10 & 48,10 & 64,50 & 56,30 & 77,90 & 70,20 \\
\hline
\end{tabular}

Sumber: Hasil Analisis.

\section{KESIMPULAN}

Secara umum dapat disimpulkan bahwa usaha bisnis penangkapan ikan tuna PT Serena Marine, dinyatakan layak secara finansial atau dapat memberikan keuntungan cukup baik. Hasil perhitungan rasio profitabilitas seperti ROA, ROI dan ROE, setelah tahun pertama menunjukkan rasio di atas 1\%, berarti akan memberikan keuntungan maksimal. Selanjutnya, perhitungan PBP menujnjukkan bahwa pengembalian modal usaha akan terjadi pada tahun ke 2,1 atau pada bulan ke 25 dari operasi PT Serena Marine. Hal ini cukup baik untuk merangsang minat para nelayan dan pengusaha lokal untuk ikut serta dalam industri penangkapan ikan di Sulawesi Utara.

Dari perhitungan kriteria investasi dengan konsep present value, diperoleh indikator NPV positif (Rp5 milyar lebih), dengan nilai BCR 1,62 dan nilai IRR $46 \%$ yang lebih besar dari suku bunga diskonto yang digunakan dalam analisis (15\%) maka rencana investasi penangkapan ikan tuna oleh PT Serena Marine di perairan Sulawesi Utara adalah menguntungkan dan layak dilaksanakan.

\section{DAFTAR PUSTAKA}

Barringer, B.R. 2009. Preparing Effective Business Plans: An Entrepreneurial Approach. Pearson Ed., New Jersey.

(BPS) Biro Pusat Statistik Provinsi Sulawesi Utara, 2012. Kelautan dan Perikanan dalam Angka. Manado.

Fauzi, A. 2005. Ekonomi Perikanan. Jakarta: Penerbit Gramedia.

FoEh, J.E.H.J. 2003. Water and Forest Protection Project. Implementation of Community-Based Forest Management in Java. Resource Economist Project Report, DFID/Perum Per-hutani, Jakarta.
Gray, C., P. Simanjuntak, L. K. Sabur, P.F.L. Maspaitella, R.C.G. 2002. Pengantar Evaluasi Proyek. Gramedia Pustaka Utama, Jakarta.

Hooley, Nigel F. Piercy, and Brigette Nicoulaud. 2008. Marketing Strategy and Competitive Positioning, Pearson Prentice Hall, New Jersey.

Ibrahim, J. 2009. Studi Kelayakan Bisnis. PT Rineka Cipta, Jakarta.

Kadariah, L. 1999. Pengantar Evaluasi Proyek. FE UI, Jakarta.

Kementerian Kelautan dan Perikanan, 2012. Peta Keragaan Perikanan Tangkap di Setiap Wilayah Perikanan Republik Indonesia (WPPRI). Edisi ke-4, Jakarta.

Prado, J. and P, Dremiere. 2005. Panduan Teknis Usaha Penangkapan Ikan. Balai Pengembangan Penangkapan Ikan, Semarang.

Perikanan-diy.info., 2007. Teknologi Penangkapan Tuna,http://www.perikanan-diy.info/home. php? mode $=$ content $\&$ submode $=$ detail $\&$ id $=205$

Rangkuti, F. 2008. Analisis SWOT Teknik Membedah Kasus Bisnis. PT Gramedia Pustaka Utama, Jakarta.

Sutojo, S., 2004. Studi Kelayakan Proyek: Konsep, Teknik dan Kasus. Seri Manajemen Bank No. 66. Damar Mulia Pustaka, Jakarta.

Tribunnews.com., 2012. Pencuri Ikan Filipina : Laut Indonesia Kaya. http://www. Tribunnews. com/2011/06/16/pencuri-ikan-filipina-lautindonesia-kaya

Umar, H. 2003. Studi Kelayakan Bisnis: Manajemen, Metode dan Kasus. Gramedia Pustaka Utama, Jakarta.

Warta Pasar Ikan. 2012. Informasi Harga Ikan Nasional dan Internasional. Edisi Januari. Jakarta: Direktorat Pemasaran dalam Negeri, Direktorat Jenderal Pengolahan dan Pemasaran Hasil Perikanan, Kementerian Kelautan dan Perikanan, Jakarta 


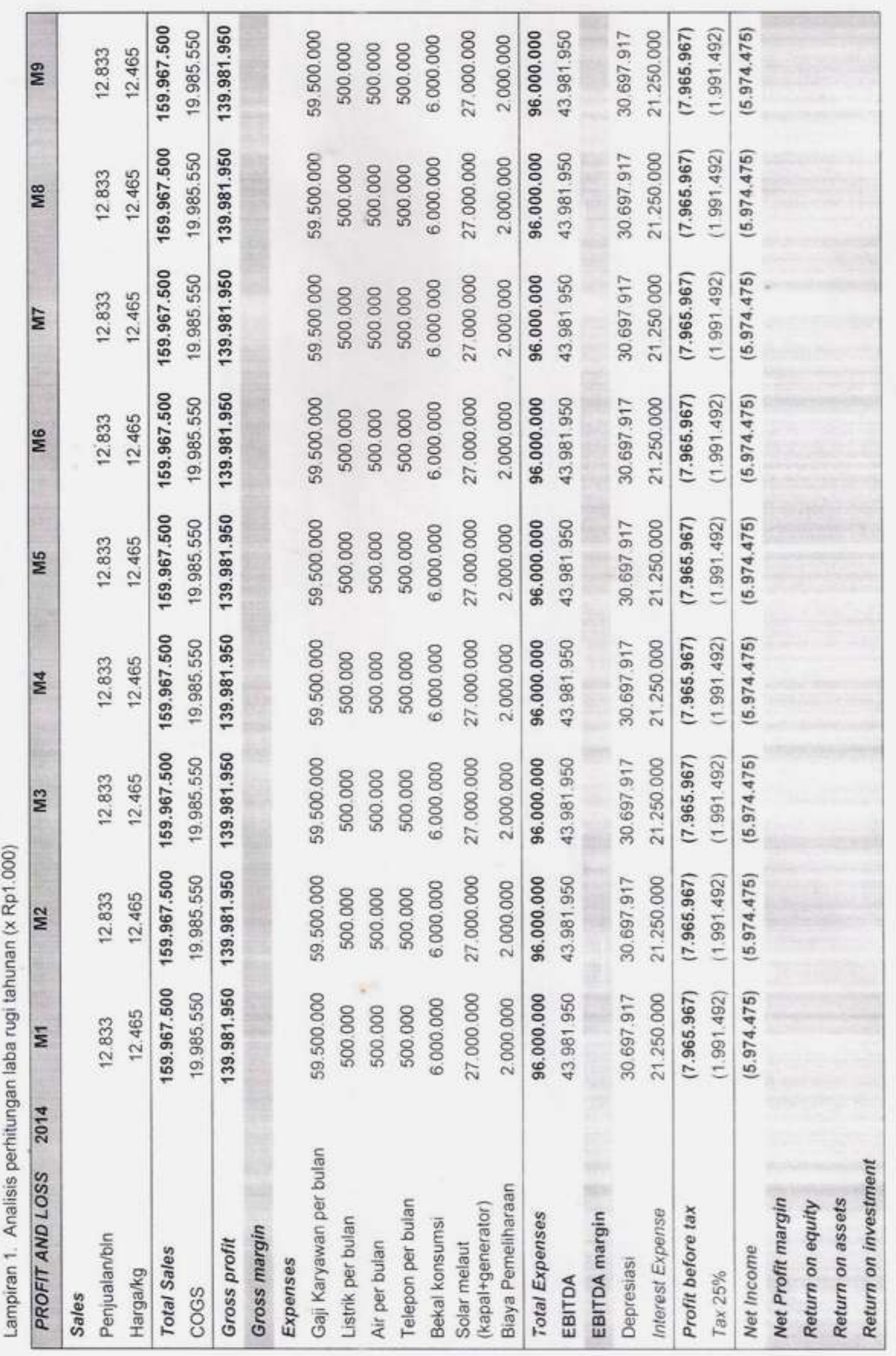




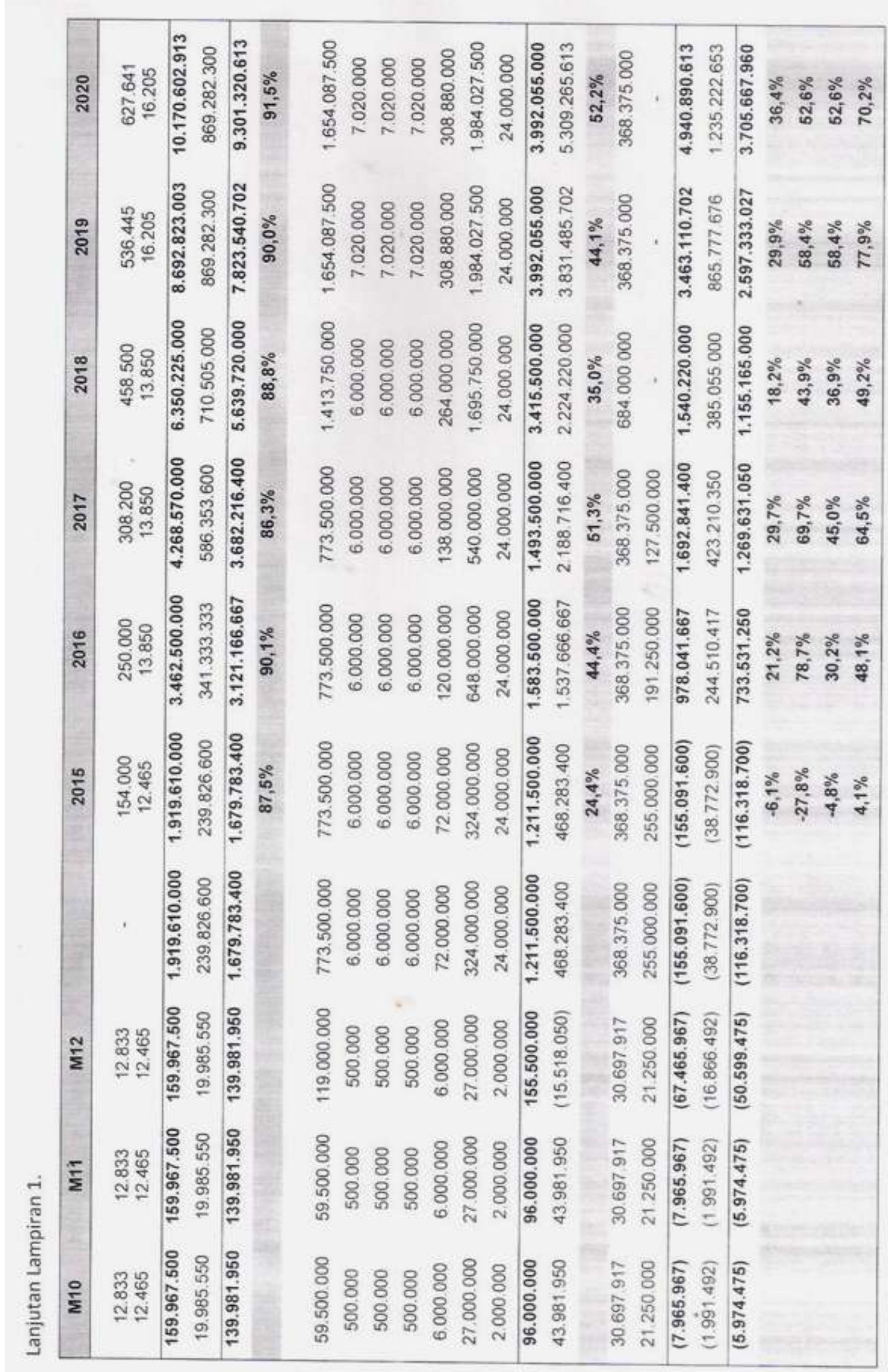




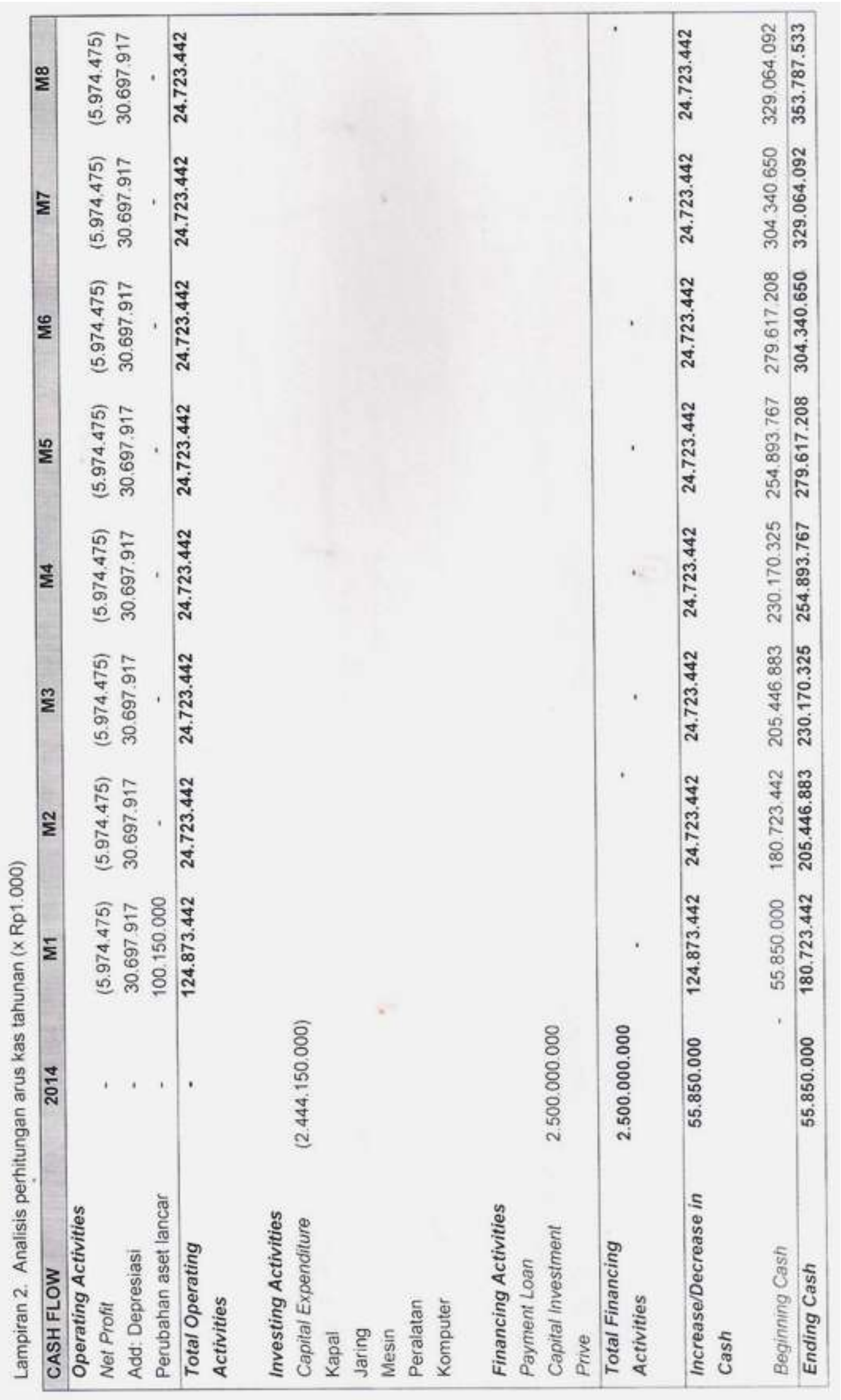




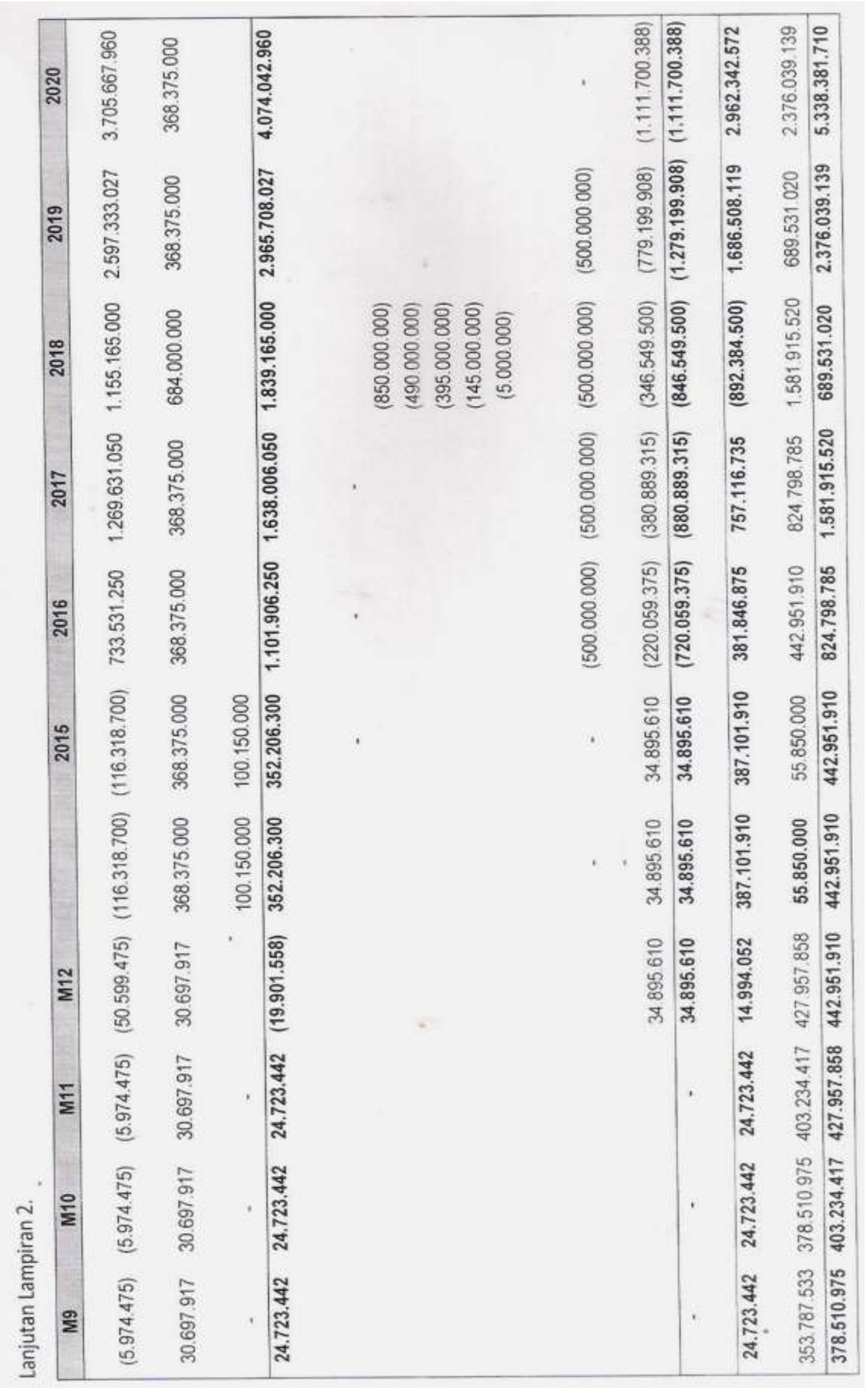




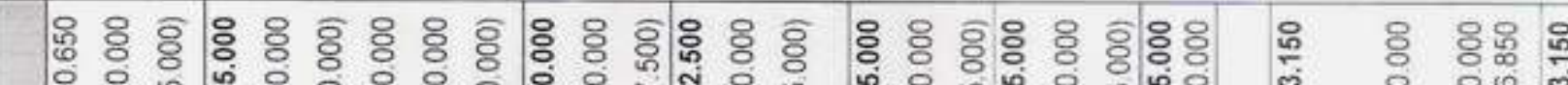
๘

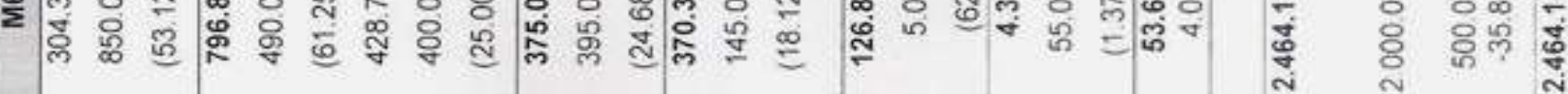

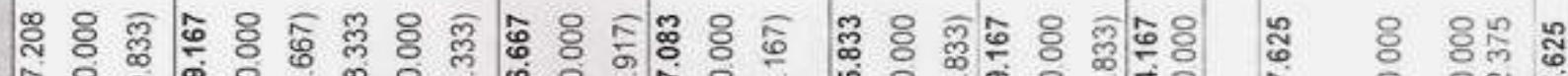
气

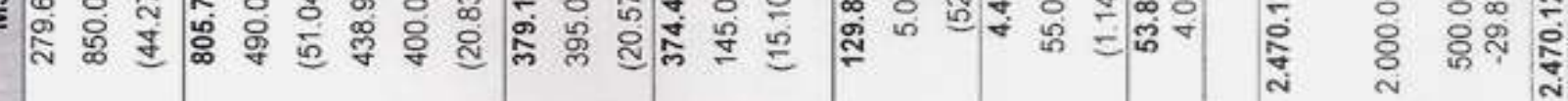

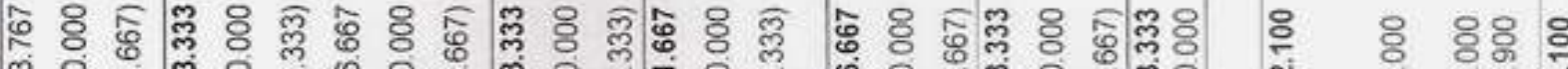

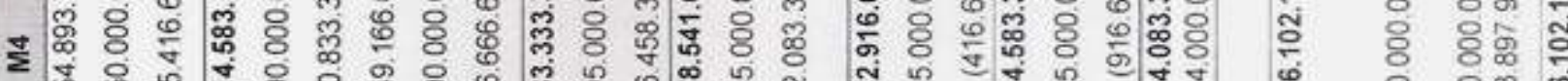

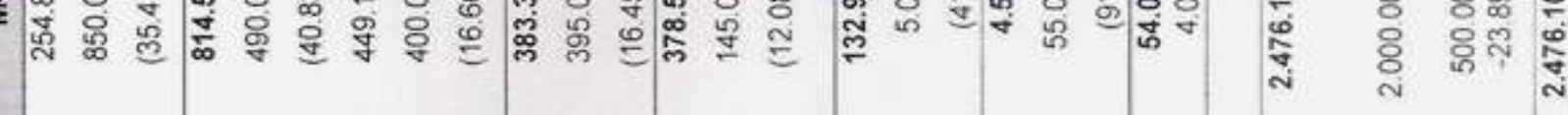

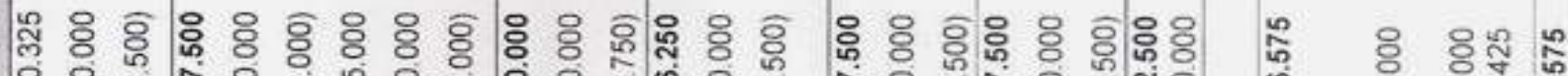

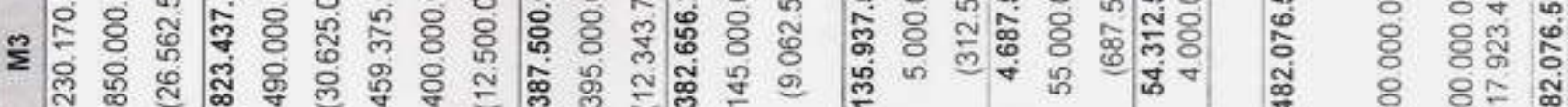

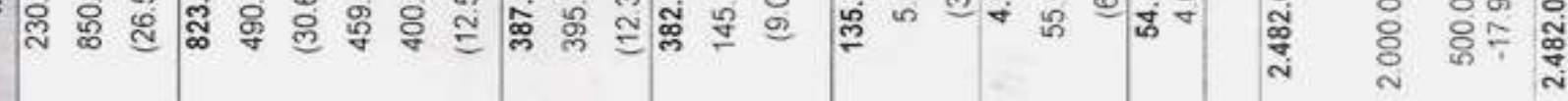

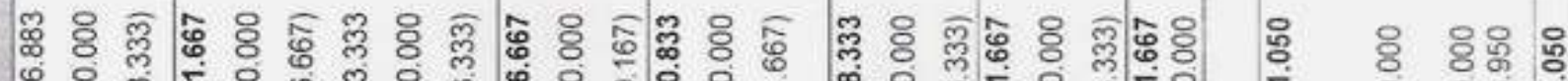

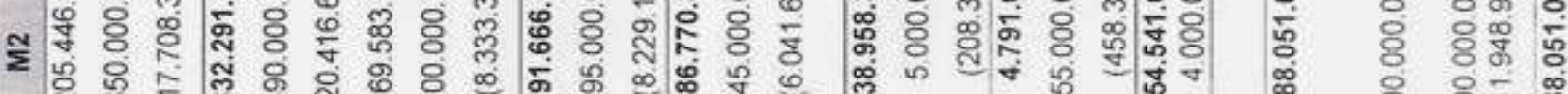

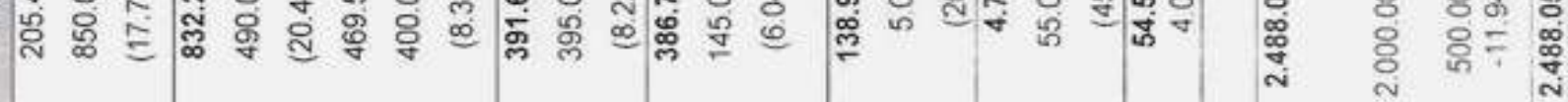

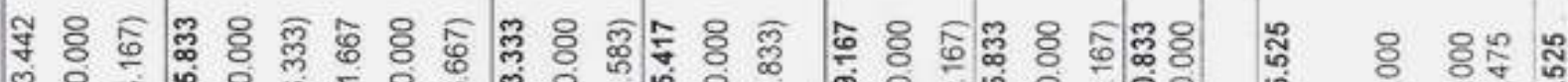

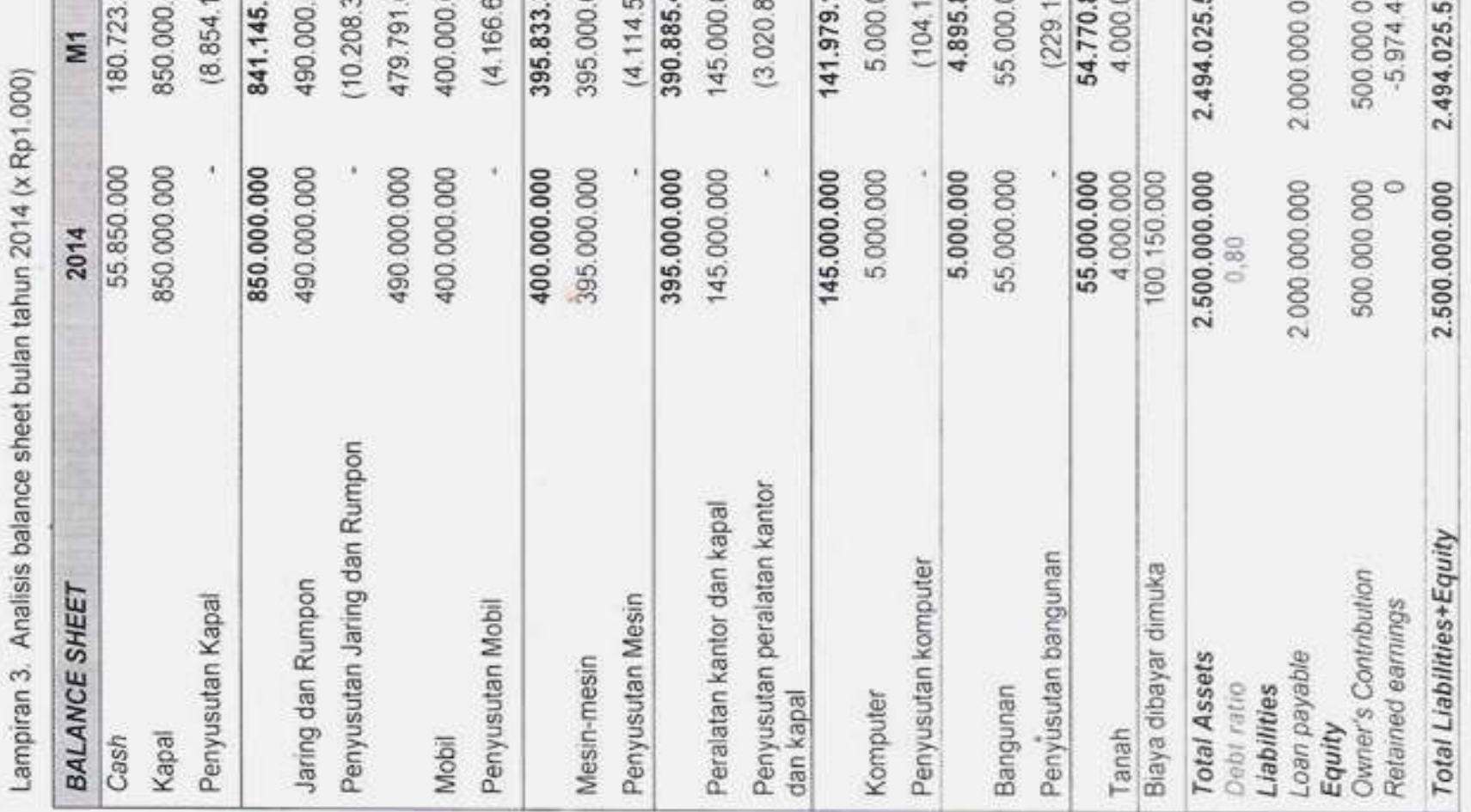




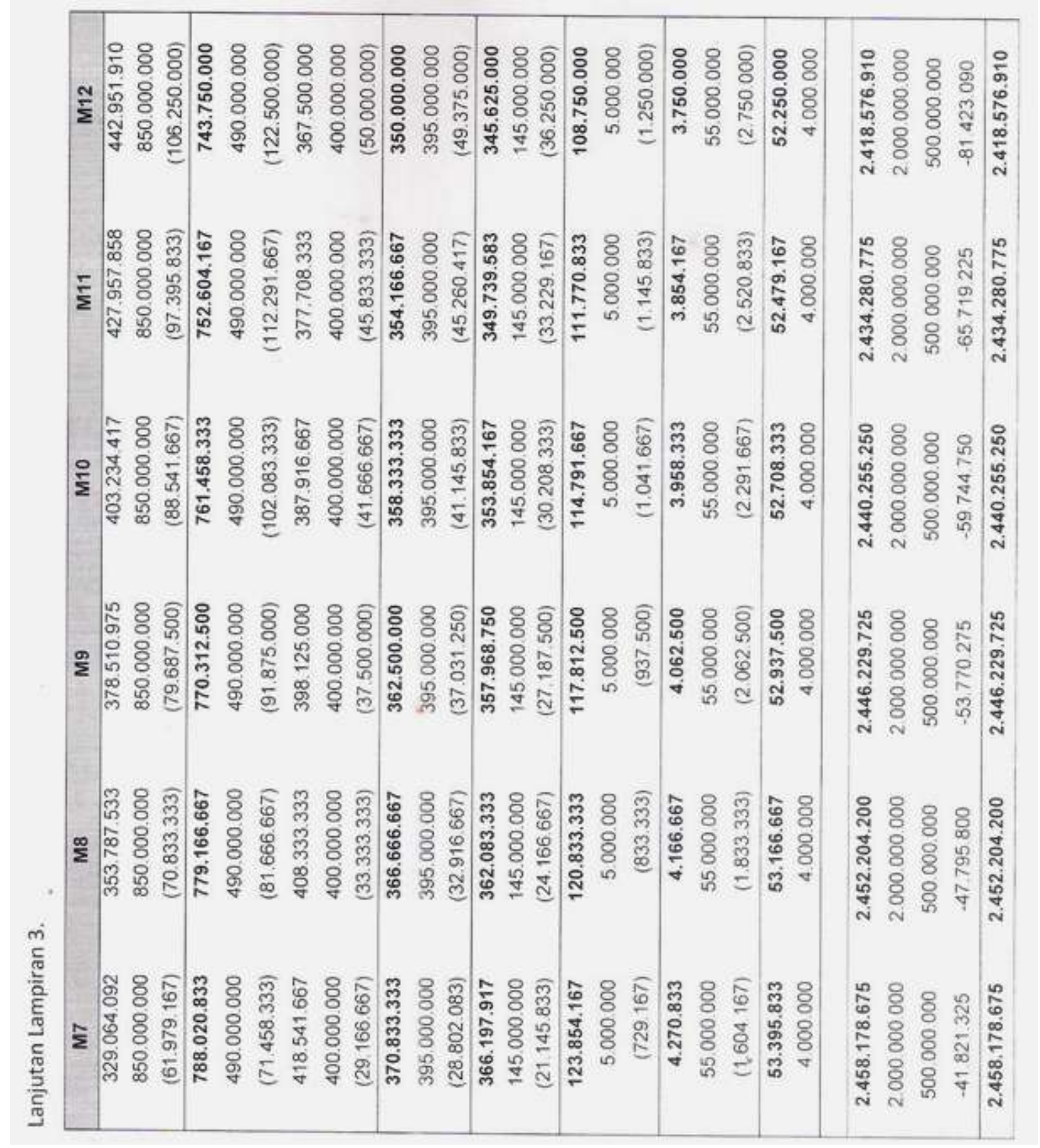




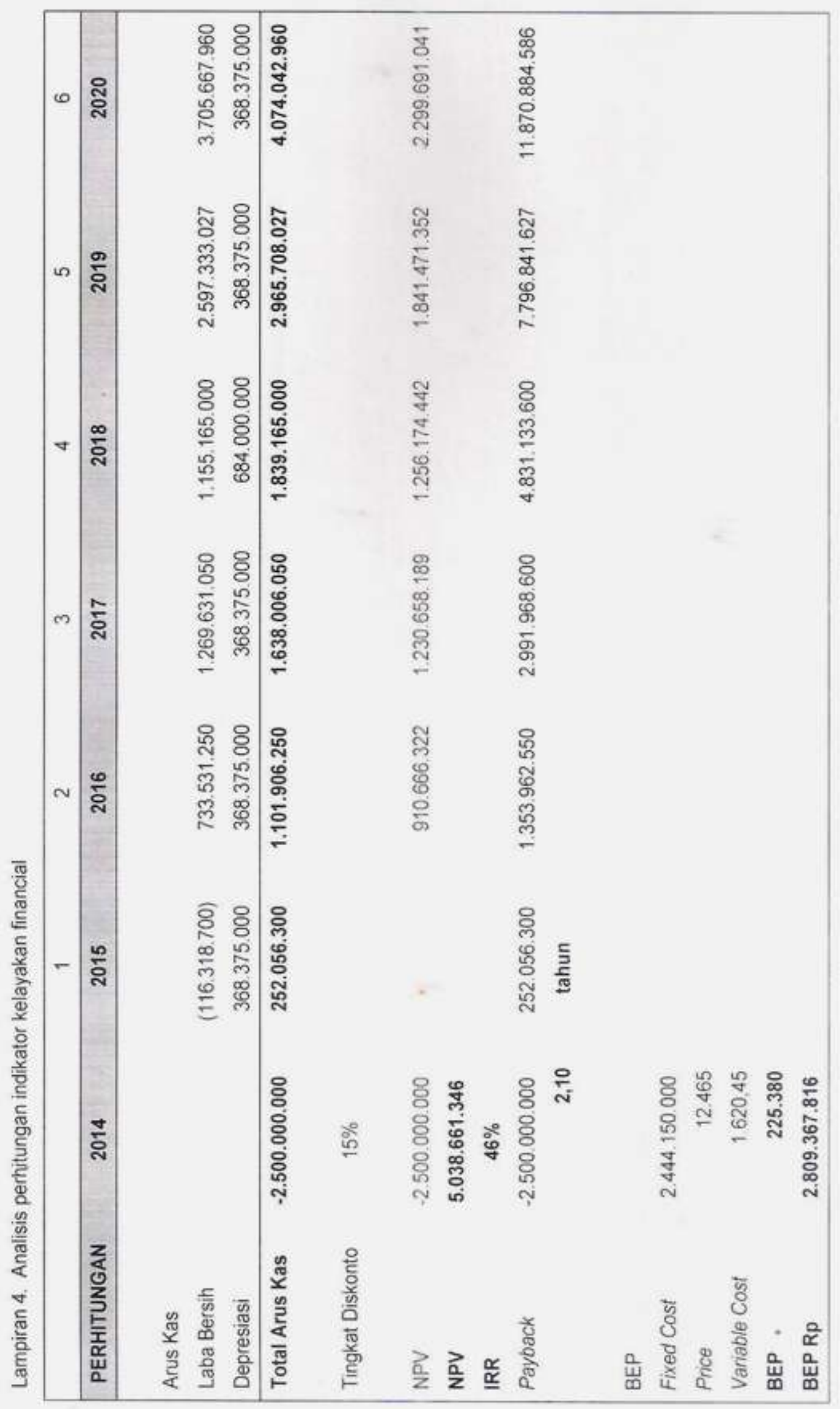

